\title{
Phytoremediation of lowland soil contaminated with a formulated mixture of Imazethapyr and Imazapic ${ }^{1}$
}

\author{
Fitorremediação de solo de terras baixas contaminado com mistura formulada de \\ imazetapir + imazapique
}

\author{
Kelen Müller Souto ${ }^{2 *}$, Luis Antonio de Avila ${ }^{3}$, Guilherme Vestena Cassol ${ }^{4}$, Sérgio Luiz de Oliveira $\mathrm{Machado}^{4}$ e \\ Enio Marchesan ${ }^{4}$
}

\begin{abstract}
The use of plants to decontaminate water and soil contaminated with both organic and inorganic pollutants is a promising technology for sustainable agriculture. The aim of this work was to evaluate the efficiency of plant species in the remediation of formulated mixtures of imazethapyr and imazapic, using the irrigated rice cultivar IRGA 417 as bioindicator. The treatments consisted of the combination of 13 plant species with seven rates of a formulated mixture of imazethapyr and Imazapic (75+25 g e.a. $\mathrm{L}^{-1}$ respectively): 0, 200, 300, 400, 500, 1000 and $4000 \mathrm{~mL} \mathrm{ha}^{-1}$. To evaluate the potential for phytoremediation in these species, symptoms of injury and plant height were measured in rice plants at 7, 14, 21 and 28 days after emergence and shoot dry weight at 28 days after emergence. Glycine max, Lolium multiflorum and Lotus corniculatus are potentially promising species in the phytoremediation of soils contaminated with the herbicide imazethapyr and imazapic (up to $4000 \mathrm{~mL} \mathrm{ha}^{-1}$ ), due to being more adapted to hydromorphic environments, which is a feature found in soils cultivated with irrigated rice. Crotalaria juncea, Canavalia ensiformis, Stizolobium aterrimum, Vicia sativa, Raphanus sativus and Triticum aestivum are species capable of the phytoremediation of soils contaminated with imazethapyr + imazapic, however the occurrence of anoxia in hydromorphic soils reduce the establishment and development of these plants.
\end{abstract}

Key words: Rice. Phytoremediation. Soil decontamination.

RESUMO - O uso de plantas para descontaminar água e solo contaminados com poluentes orgânicos e inorgânicos é uma tecnologia promissora para a agricultura sustentável. Este trabalho teve como objetivo avaliar a eficiência de espécies vegetais na remediação da mistura formulada de imazetapir + imazapique, utilizando a cultivar de arroz irrigado IRGA 417 como planta bioindicadora. Os tratamentos foram compostos pela combinação entre 13 espécies vegetais e sete doses da mistura formulada de imazetapir + imazapique (75 + 25 g e.a. $\mathrm{L}^{-1}$, respectivamente): zero, 200; 300; 400; 500; 1.000 e $4.000 \mathrm{~mL} \mathrm{ha}^{-1}$. Para a avaliação do pontecial fitorremediador dessas espécies foram avaliadas a altura e sintomas de fitointoxicação nas plantas de arroz irrigado, aos 7; 14; 21 e 28 dias após a emergência, e massa seca da parte aérea aos 28 dias após a emergência. Glycine max, Lolium multiflorum e Lotus corniculatus por serem mais adaptadas a ambientes hidromórficos, característica essa encontrada em solos cultivados com arroz irrigado, são espécies potencialmente promissoras em fitorremediar solos contaminados com o herbicida imazetapir + imazapique (até $4.000 \mathrm{~mL} \mathrm{ha}^{-1}$ ). Crotalaria juncea, Canavalia ensiformis, Stizolobium aterrimum, Vicia sativa, Raphanus sativus e Triticum aestivum são espécies capazes de fitorremediar solos contaminados com imazetapir + imazapique, porém a ocorrência de anoxia em solos hidromórficos dificultam o estabelecimento e desenvolvimento das plantas.

Palavras-chave: Arroz. Fitorremediação. Descontaminação de solo.

\footnotetext{
*Autor para correspondência

Recebido em 07/11/2012; aprovado em 09/11/2014

Trabalho realizado como parte da Dissertação de Mestrado da primeira autora, apresentado ao programa de Pós-graduação em Agronomia da Universidade Federal de Santa Maria, Santa Maria- RS, Brasil

2Departamento de Defesa Fitossanitária, Universidade Federal de Santa Maria, Santa Maria-RS, Brasil, kelenmuller85@ gmail.com

${ }^{3}$ Departamento de Fitossanidade, Universidade Federal de Pelotas, Pelotas-RS, Brasil, laavila@ gmail.com

${ }^{4}$ Departamento de Fitotecnia, Universidade Federal de Santa Maria, Santa Maria-RS, Brasil, guivcassol@bol.com.br; slomachado@yahoo.com.br; eniomarchesan@gmail.com
} 


\section{INTRODUCTION}

Long-term persistence of herbicides in the soil can limit the rotation of crops and potentiate environmental contamination (DAN et al., 2011). Among these compounds are the herbicides imazethapyr and imazapic, which belong to the imidazolinone group of chemicals, widely used in irrigated rice fields as the main alternative in controlling red rice. The herbicide imazethapyr has a pKa of 2.1 and 3.9 and imazapic of 2.0, 3.9 and 11.1, which characterises them as weak acids (SENSEMAN, 2007), having a half-life $\left(\mathrm{t}_{1 / 2}\right)$ of from 60 to 90 days, and 120 days respectively (SENSEMAN, 2007). They also have high solubility in water, $1400 \mathrm{mg} \mathrm{L}^{-1}$ for imazethapyr and $2200 \mathrm{mg} \mathrm{L}^{-1}$ for imazapic. These characteristics among others, cause the compounds to be highly influenced by the surrounding environment.

One of the characteristics most looked for in a herbicide is that it remain active in the environment long enough for effective weed control; however, the presence of the herbicide in the soil can become undesirable, and may result in problems with non-tolerant crops that may be grown later (PROCÓPIO et al., 2008). For herbicides of the imidazolinone group of chemicals, research shows that their continuing presence in the soil causes a smaller stand of plants in non-tolerant rice due to the residual effect of the association of imazethapyr with imazapic, but without any effect on productivity (VILLA et al., 2006). Marchesan et al. (2011) found however that the residual effect of these herbicides caused losses in production of $19 \%$ for imazethapyr and $30 \%$ for imazapic in genotypes of sensitive rice.

Studies show that cultivation of certain plant species can decontaminate areas where xenobiotics are present, such as herbicides with a long residual effect on the soil (D'ANTONINO et al., 2009). This process is known as phytoremediation (SULMON et al., 2007) and can shorten the time needed to free the area for the cultivation of plant species which are non-tolerant to the more persistent herbicides.

Compared with the selection of plants in the decontamination of trace elements, the limitations encountered in selecting plant species for the remediation of herbicides are complex, as these display great molecular diversity in the face of the constant changes they are subject to (PIRES et al., 2003). Furthermore, there is the drawback of the contaminant (herbicide) having been developed to control the contanimator, in this case, the weeds. Given that not all plant species are able to develop in contaminated environments, the first step is the identification of those species which are not only suitable for the local conditions, but are also tolerant of the contaminant (MARQUES et al., 2011).
The next step is to evaluate the capacity of the tolerant plant to promote decontamination of the soil. Efficiency of the phytoremediation process is generally measured by the reduction of the contaminant in the soil to concentrations below the required reference values and time (MARQUES et al., 2011). When a plant is used which is capable of reducing the concentration of herbicides in the soil, what is achieved is to bring forward the production of crops of economic interest which were previously not able to be grown in certain areas (DAN et al., 2011). In view of the above, the aim of this work was to evaluate the efficiency of plant species in the remediation of lowland soil contaminated with a formulated mixture of imazethapyr and imazapic $\left(75+25\right.$ g a.e. $\left.\mathrm{L}^{-1}\right)$.

\section{MATERIAL AND METHODS}

The experiments were carried out in a plastic greenhouse with no air conditioning, at two times, according to the growing season (autumn-winter and spring-summer), in the crop years of 2009/2010. The Ahorizon of the soil was used as substrate, classified as a hydromorphic eutrophic arenic Planosol (EMPRESA BRASILEIRA DE PESQUISA AGROPECUÁRIA, 2006), from the experimental area of the Palma Agricultural Centre, at the Federal University of Pelotas (UFPel), Capão-do-Leão Campus, in the state of Rio Grande do Sul, Brazil (RS). The soil is of a silty-loam texture with the following characteristics: $\mathrm{pH}$ water $(1: 1)=6.2$, clay content $=200 \mathrm{~g} \mathrm{~kg}^{-1}$, organic matter content $=32 \mathrm{~g} \mathrm{~kg}^{-1}, \mathrm{P}=16.2 \mathrm{mg} \mathrm{dm}^{-3}, \mathrm{~K}=180 \mathrm{mg} \mathrm{dm}^{-3}, \mathrm{Ca}$ $=5.5 \mathrm{cmol}_{\mathrm{c}} \mathrm{dm}^{-3}, \mathrm{Mg} \mathrm{cmol}_{\mathrm{c}}=3.2 \mathrm{dm}^{-3}, \mathrm{Al}=0.0 \mathrm{cmol}_{\mathrm{c}} \mathrm{dm}^{-3}$ and SMP index $=6.6$.

The autumn-winter experiment was carried out from April to July of 2009 in a randomised block design with an $8 \times 7$ factorial scheme and four replications. The treatments consisted of a combination of coolseason plant species: Avena strigosa (oat), Lolium multiflorum (ryegrass), Lotus corniculatus (birdsfoot trefoil), Raphanus sativus (wild radish), Secale cereale (rye), Triticum aestivum (wheat) and Vicia sativa (common vetch), and a control treatment with no prior cultivation; seven doses of herbicide, made up from the formulated mixture of imazethapyr and imazapic $\left(75+25 \mathrm{~g}\right.$ a.e. $\left.\mathrm{L}^{-1}\right)$ at rates of $0,200,300,400,500,1000$ and $4000 \mathrm{~mL} \mathrm{ha}^{-1}$ in polyethylene pots, $13 \mathrm{~cm}$ in diameter and $9.5 \mathrm{~cm}$ in height, at the density recommended for each crop for a soil volume of $1.0 \mathrm{dm}^{3}$. Choice of the species and rates of the herbicide were based on preliminary studies, carried out by the authors, of the tolerance of cultivated plants to the herbicide. 
Application was performed 48 hours before seeding, using a precision pipette to add the solutions with the herbicide to the soil surface. After application, the soil was turned, and then received a sufficient volume of water to reach field capacity, thereby allowing homogeneous distribution of the herbicide throughout the experimental unit. The pots were maintained under daily irrigation, in order to keep the soil moisture at around $80 \%$ of field capacity.

At 60 days after emergence, the plants were removed from the pots by cutting the stems at surface height, without removing the roots. The genotype IRGA 417, not resistant to the herbicide, was sown in each pot and used as a test with the intention of evaluating the potential for phytoremediation of each species previously grown in the soil contaminated by the herbicide.

After emergence of the rice, the plants were thinned, leaving four plants per pot. To determine the potential for phytoremediation of each species, injury (PT) was evaluated and the plant height (ALT) and dry weight (DM) of the shoots were determined. Symptoms of injury were evaluated by comparison with the control treatment, assigning scores from 0 to 100 , corresponding respectively to the absence of symptoms to death of the plant (FRANS et al., 1986). The plant height was evaluated by measuring the plants from the surface of the soil to the insertion point of the highest leaf. Both assessments were carried out at 7,14,21 and 28 days after emergence (DAE), when the rice plants were cut close to the ground to determine the dry weight, obtained by weighing the harvested material after drying in a forced circulation oven $\left(70 \pm 2{ }^{\circ} \mathrm{C}\right)$ for 72 hours.

The spring-summer experiment was carried out from October of 2009 to January of 2010 in an experimental design of randomised blocks in a $5 \times 7$ factorial scheme with four replications. The treatments consisted of a combination of warm-season plant species: Canavalia ensiformis (jack bean), Crotalaria juncea (sunn hemp), Glycine max (soybean) and Stizolobium aterrimum (velvet bean), plus a control treatment with no prior cultivation; seven doses of herbicide, made up from the formulated mixture of imazethapyr and imazapic $\left(75+25 \mathrm{~g}\right.$ a.e. $\left.\mathrm{L}^{-1}\right)$ at dosages of $0,200,300,400,500,1000$ and $4000 \mathrm{~mL}$ $\mathrm{ha}^{-1}$, following the same methodology used in the autumnwinter experiment.

The data were tested for assumptions for the mathematical model and subjected to procedures of variance analysis and polynomial regression, using the SAS software for statistical analysis and SigmaPlot ${ }^{\circledR}$ for elaboration of the dose-response curves, determined by the three-parameter log-logistic model (SEEFELDT; JENSEN; FUERST, 1995), as below (Equation 1):

$$
y=\frac{a}{\left[1+\left(\frac{x}{x_{0}}\right)^{b}\right]}
$$

where: $y=$ percentage of control; $x=$ herbicide dosage; and $\mathrm{a}, \mathrm{x} 0$ and $\mathrm{b}=$ parameters of the equation, with a being the difference between the maximum and minimum points of the curve, $\mathrm{x} 0$ being the dosage giving a $50 \%$ response for the variable, and $b$ the slope of the curve.

The logistic model has advantages, since one of the terms of the equation is an estimate of the value of $\mathrm{GR}_{50}$ (growth reduction by $50 \%$ ), which is the dosage of herbicide which gives a biological effect of $50 \%$ (CHRISTOFFOLETI; LOPEZ-OVEJERO, 2004). From the values for $\mathrm{GR}_{50}$, the remediation factor (FRem) was obtained for each combination of species being studied.

The FRem was calculated by dividing the values for $\mathrm{GR}_{50}\left(\mathrm{PT}_{50}, \mathrm{ALT}_{50}, \mathrm{DM}_{50}\right)$ of the irrigated rice plants, grown in soil with residual herbicide which received the potentially phytoremediative plant species, by those obtained in soil that received no plant species during crop succession and that also received no applications of herbicide (control), according to a methodology adapted from Hall, Strome and Horsman (1998).

\section{RESULTS AND DISCUSSION}

Through the analysis of the dose-response curves of the species under study, an interaction was seen between the factors plant species and dosages of the herbicide mixture, a significant effect being noted $(\mathrm{P} \leq 0.05)$ from the residual of the formulated mixture of imazethapyr and imazapic $\left(75+25\right.$ g a.e. $\left.\mathrm{L}^{-1}\right)$ on the variables plant height, injury and dry weight, analysed in the non-tolerant rice plants, IRGA 417, sown in succession to the species $A$. strigosa, L. multiflorum, S. cereale, L. corniculatus, $C$. juncea, V. sativa, C. ensiformis, S. aterrimum, R. sativus, G. max, T. aestivum, and also when there was no previous crop (control) (Table 1).

It was seen that an increase in herbicide dosage resulted in plants of lesser height (Figure 1) and shoot dry weight (Figure 3) and more intense symptoms of injury (Figure 2), varying with the species being tested. Similar results were found by Madalão et al. (2013) with Crotalaria juncea, Canavalia ensiforrmis and Stizolobium aterrimum grown in five dosages of the herbicide sulfentrazone. The evaluation carried out at 21 DAE was chosen for construction of the doseresponse curves, as the recovery capacity of rice plants from that stage of development is known (WEBSTER; MASSON, 2001). 
Table 1 - Variance analysis of the variables plant height, injury and dry weight, analysed in the non-tolerant rice plants, IRGA 417 , sown in succession to the species under test

\begin{tabular}{|c|c|c|c|c|}
\hline \multirow{2}{*}{ Sources of variation } & \multirow{2}{*}{ GL } & \multicolumn{3}{|c|}{ 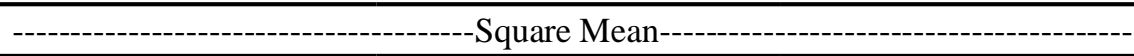 } \\
\hline & & Plant Height & Injury & Dry Weight \\
\hline Blocks & 3 & $43.27(0.0001)^{*}$ & $53.14(0.0842)$ & $553.02(0.0000)$ \\
\hline Crops & 7 & $333.28(0.0000)$ & $2,955.45(0.0000)$ & $5,615.90(0.0000)$ \\
\hline Rates & 12 & $4,624.99(0.0000)$ & $60,626.07(0.0000)$ & $50,879.06(0.0000)$ \\
\hline Rates $\mathrm{x}$ crops & 72 & $42.35(0.0000)$ & $389.98(0.0000)$ & $457.80(0.0000)$ \\
\hline Residual & 269 & $5.65(0.0000)$ & $23.73(0.0000)$ & $23.98(0.0000)$ \\
\hline $\mathrm{CV}(\%)$ & & 13.01 & 11.74 & 10.13 \\
\hline
\end{tabular}

*significance level of $5 \%$ by F-test

Figure 1 - Dose-response curves of cool-season (a) and warm-season species (b) to a formulated mixture of imazethapyr and imazapic $\left(75+25\right.$ g a.e. $\left.\mathrm{L}^{-1}\right)$, evaluated through the reduction in plant height of non-tolerant rice (IRGA 417) at 21 days after emergence (DAE), compared to the control. Santa Maria, RS

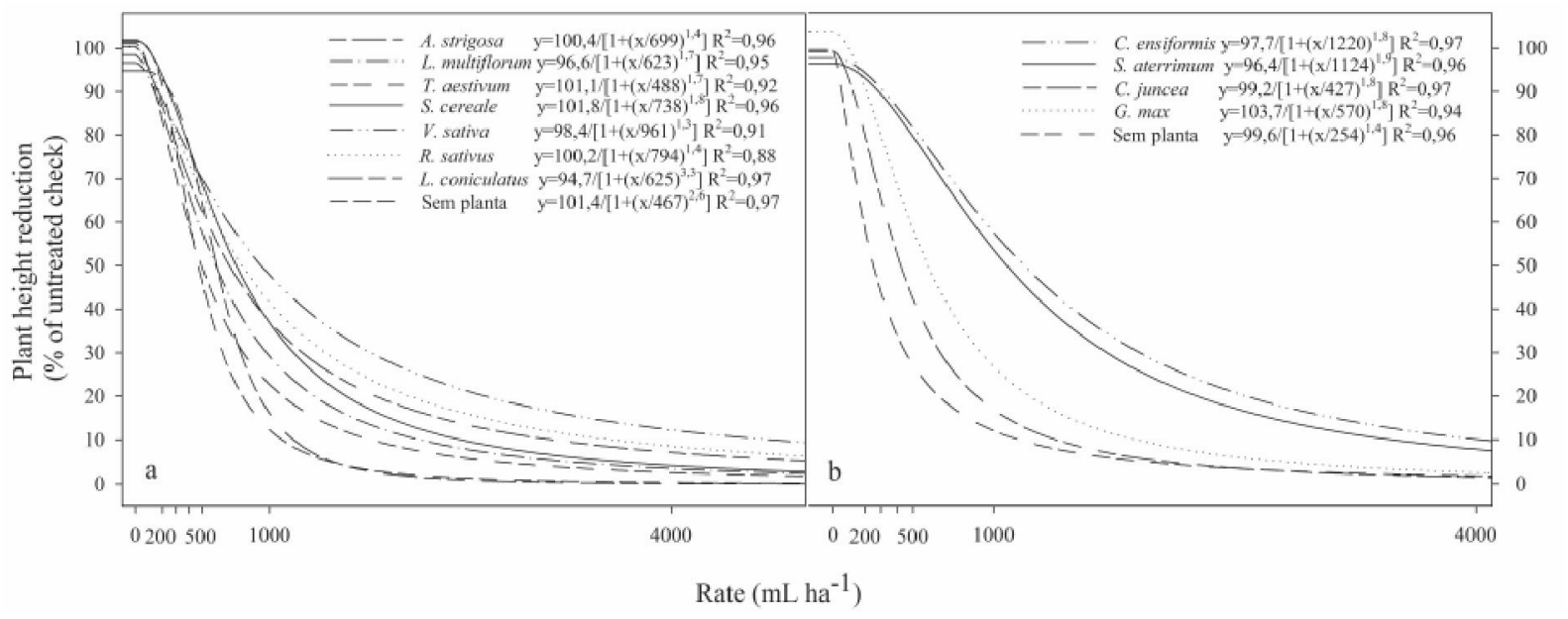

Figure 2 - Dose-response curves of cool-season (a) and warm-season species (b) to a formulated mixture of imazethapyr and imazapic $\left(75+25 \mathrm{~g}\right.$ a.e. $\left.\mathrm{L}^{-1}\right)$, evaluated through the injury of non-tolerant rice plants (IRGA 417) at 21 days after emergence (DAE), compared to the control. Santa Maria, RS

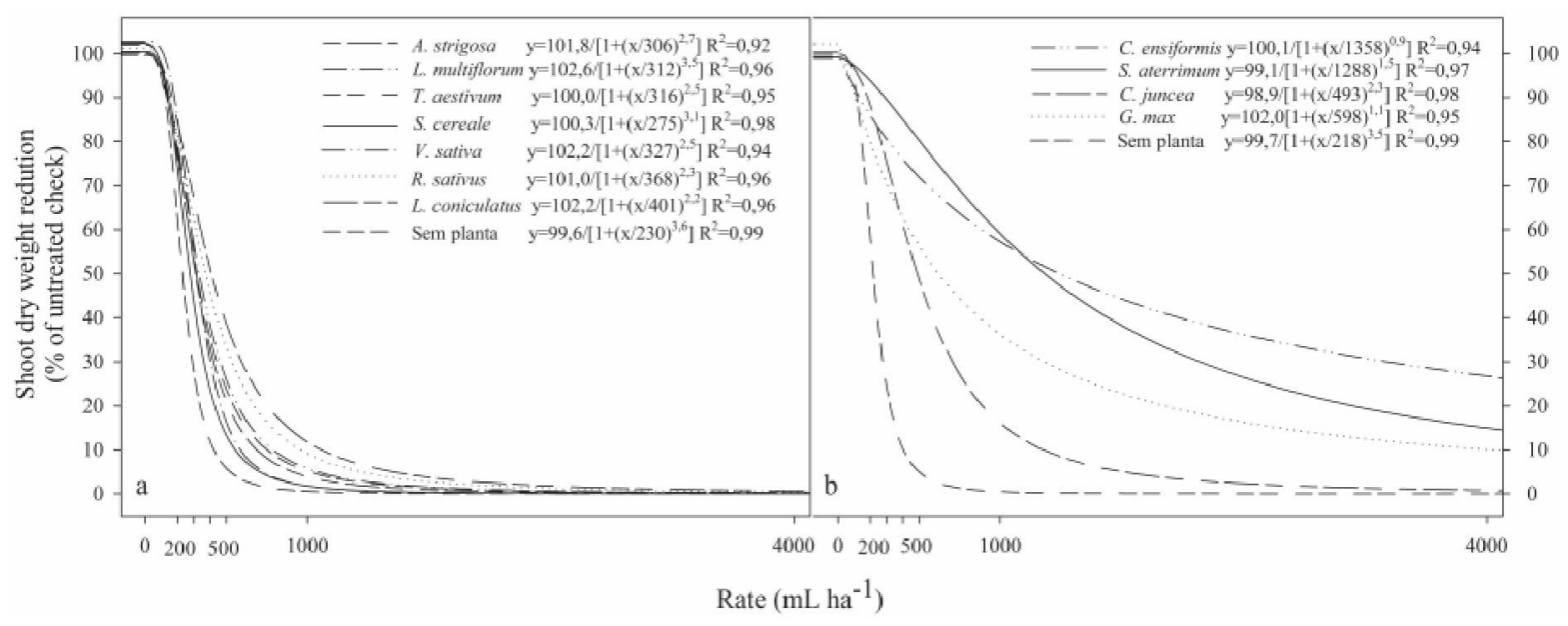


Figure 3 - Dose-response curves of cool-season (a) and warm-season species (b) to a formulated mixture of imazethapyr and imazapic $\left(75+25\right.$ g a.e. $\left.\mathrm{L}^{-1}\right)$, evaluated through the shoot dry matter of non-tolerant rice plants (IRGA 417) at 21 days after emergence (DAE), compared to the control. Santa Maria, RS

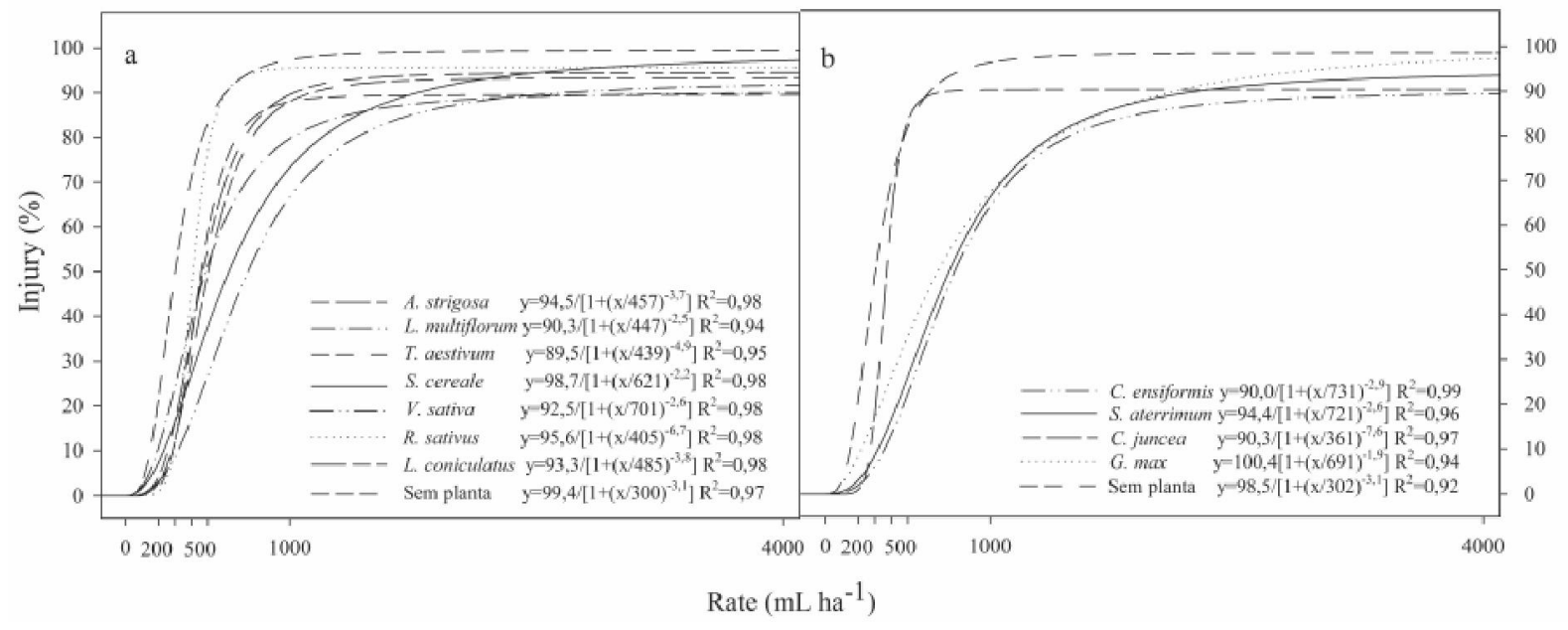

As different species are high lighted for each dependent variable analysed, results were evaluated for the remediation factor of each species on the dependent variable shoot dry weight $\left(\mathrm{DM}_{50}\right)$. This variable was used as a basis because rice-grain production is related to the production of shoot dry weight, through organic farming and the harvest index, HI (YOSHIDA, 1981).

The estimated values of $\mathrm{GR}_{50}$ for shoot dry weight therefore show that the cool-season species, $L$. corniculatus, L. multiflorum, A. sativum, $V$. sativa and $T$. aestivum, present a potential for the phytoremediation of soil contaminated with the herbicide mixture employed, since the values observed for $\mathrm{GR}_{50}$ were significantly higher than those obtained with the treatment with no prior cultivation in the winter (control), there being no overlap between the confidence intervals, demonstrating the effect of these species in reducing the residual herbicide.

Similarly, the warm-season species, $C$. juncea, $C$. ensiformis, S. aterrimum and G. max, demonstrated a potential for the phytoremediation of the herbicide employed, since values for $\mathrm{GR}_{50}$ for shoot dry weight were seen which were higher than the control (without cultivation in the summer); whereas the species A. strigosa and S. cereale did not differ significantly from the treatment used as control (soil without cultivation in the winter) (Table 2). In general, the results make it possible to infer that $C$. juncea, $C$. ensiformis, $S$. aterrimum, V. sativa, $R$. sativus and T. aestivum are species which are potentially capable of the phytoremediation of soils contaminated with imazethapyr and imazapic, however the anoxia occurring in hydromorphic soils impedes the establishment and development of plants. Similar results were found by Procópio et al. (2005a), where the species,
V. sativa, exposed to treatment with the herbicide, trifloxysulfuron-sodium, despite not having provided a shoot dry weight in beans equal to that of $S$. aterrimum and $C$. ensiformes, was superior to the other treatments.

The results seen in this study also confirm the findings of Correa et al. (2008), who claim that the species $C$. ensiformis and S. aterrimum are plants with a potential for the phytoremediation of areas treated with the herbicide diclosulam. For Procópio et al. (2005a), prior cultivation with $S$. aterrimum at any of the tested population densities, prevented reduction in the shoot dry weight of bean plants, caused by the presence of trifloxysulfuron-sodium in the cultivated soil.

The values for $\mathrm{MS}_{50}$ ranged from 275 to $1,358 \mathrm{mg}$ ha ${ }^{1}$, demonstrating that the rate required to cause a $50 \%$ reduction in the dry matter of rice plants was from one to six times higher when compared to the soil with no previous cultivation (Table 2). According to Spilborghs and Casarini (1998), places with vegetation exhibit complete and more rapid biodegradability compared to non-vegetated areas, due to the expansion of the active population of soil microorganisms (rhizosphere) which use the fraction exuded from the roots (rhizodeposition) as a source of food. Also according to the same authors, the increase in the biodegradability of herbicide molecules can take place because some plants have the ability to produce enzymes that metabolically convert organic contaminants, contributing to their faster oxidation by the microorganisms present in the soil.

According to Pires et al. (2003), the use of phytoremediation is based on the natural or developed 
tolerance that some species exhibit to certain types of compounds or action mechanisms. It can thus be inferred that the results obtained in this study may be explained by the capacity the plants have to metabolise (phytodegradation) the herbicide in question into compounds which are nontoxic (or less toxic) to the plant and the environment, or simply their ability to compartmentalise the molecules of the herbicide. As the mass of the shoots of previously grown plants was removed, the herbicide could have been removed too, either compartmentalised in some reservestorage organ, or adhering to the lignin of the cell wall, thus allowing the normal development of the rice plants.

Another possibility is phytostimulation, in which there is stimulation of microbial activity promoted by the release of root exudates that act by degrading the compound in the soil, which in some plants characterizes a rhizospheric aptitude for bioremediation (PIRES et al., 2003). Some studies indicate that $S$. aterrimum and $C$. ensiformis are effective in decontaminating soils containing residues of the herbicides, trifloxysulfuron-sodium and tebuthiuron; and that the probable mechanism involved in decontamination is the interaction between phytostimulation and phytodegradation (PROCÓPIO et al., 2005b).

In another study in an area contaminated with sodium trifloxysulfuron, maintaining or removing the shoots of $C$. ensiformis and $S$. aterrimum after the period of phytoremediation, did not affect the subsequent development of bean plants, indicating a possible internal degradation of the product in the tissues (phytodegradation), or desactivation by other rhizospheric mechanisms, probably phytostimulation of the microbiota associated with the rhizosphere (PROCÓPIO et al., 2006). Souto et al. (2013) proved that plants of Stizolobium aterrimum release rhizodeposits that stimulate existing microbial activity in the rhizosphere upon degrading molecules of a formulated mixture of imazethapyr and imazapic present in soil under rice cultivation.

Each species has specific characteristics for removing, immobilising or transforming certain contaminants. In the present study, it can be seen that the plants which displayed more intense remediation factors were leguminous; and probably the greater contribution of nitrogen to the soil provided by these species compared to species of grass (CARVALHO et al., 2010), resulted in the better development of the bio-indicator plant. Normally leguminous plants also have a higher lignin content compared to grasses (FUKUSHIMA; SAVIOLI, 2001), and so favour sorption of the herbicides imazethapyr and imazapic in organelles which are rich in the compound, decreasing its availability in the soil.

Table 2 - Effect of the cultivation of plants in the off season, at a herbicide rate causing $50 \%$ injury $\left(\mathrm{PT}_{50}\right), 50 \%$ reduction in plant height $\left(\mathrm{ALT}_{50}\right)$ at $21 \mathrm{DAE}$, and $50 \%$ reduction in shoot dry weight $\left(\mathrm{DM}_{50}\right)$ at $28 \mathrm{DAE}$, in non-tolerant rice plants (IRGA 417), and the respective remediation factors (FRem). Santa Maria, RS

\begin{tabular}{|c|c|c|c|c|c|c|}
\hline \multirow{2}{*}{ Cultivated cool-season species } & $\mathrm{TP}_{50}$ & FRem $^{1}$ & $\mathrm{ALT}_{50}$ & FRem & $\mathrm{MS}_{50}$ & FRem \\
\hline & \multicolumn{6}{|c|}{ After the cultivation of cool-season species } \\
\hline No plants in the winter & \multicolumn{2}{|c|}{300} & \multicolumn{2}{|c|}{467} & \multicolumn{2}{|c|}{230} \\
\hline Raphanus sativus & $405^{*}$ & 1,3 & $794 *$ & 1,7 & $368 *$ & 1,6 \\
\hline Triticum aestivum & $440^{*}$ & 1,4 & $488^{\mathrm{ns}}$ & 1,0 & $316^{*}$ & 1,3 \\
\hline Lolium multiflorum & $457 *$ & 1,5 & $623 *$ & 1,3 & $312 *$ & 1,3 \\
\hline Avena strigosa & $460 *$ & 1,5 & $699 *$ & 1,5 & $306^{\mathrm{ns}}$ & 1,3 \\
\hline Lotus corniculatus & $485^{*}$ & 1,6 & $625^{*}$ & 1,3 & $401 *$ & 1,7 \\
\hline Secale cereale & $621 *$ & 2,0 & $738 *$ & 1,6 & $275^{\mathrm{ns}}$ & 1,2 \\
\hline Vicia sativa & $701 *$ & 2,3 & $961 *$ & 2,0 & $327 *$ & 1,4 \\
\hline Cultivated warm-season species & \multicolumn{6}{|c|}{ After the cultivation of warm-season species } \\
\hline No plants in the summer & \multicolumn{2}{|c|}{302} & \multicolumn{2}{|c|}{254} & \multicolumn{2}{|c|}{218} \\
\hline Crotalaria juncea & $361 *$ & 1,2 & $427 *$ & 1,7 & $494 *$ & 2,3 \\
\hline Stizolobium aterrimum & $722 *$ & 2,4 & $1125^{*}$ & 4,4 & $1289 *$ & 5,9 \\
\hline Canavalia ensiformis & $732 *$ & 2,4 & $1220^{*}$ & 4,8 & $1358 *$ & 6,2 \\
\hline Glycine $\max$ & $691 *$ & 2,2 & $1142 *$ & 4,5 & $598^{*}$ & 2,7 \\
\hline
\end{tabular}

${ }_{\text {ns }}$ Value for GR $\mathrm{GR}_{50}$ does not differ from the control (no plant) by overlapping of the confidence intervals for the values at $95 \%$ probability. $*$ Value for $\mathrm{GR}_{50}$ differs from the control (no plant) by non-overlapping of the confidence intervals for the values at $95 \%$ probability 
In experiments conducted with rice, Martini et al. (2011) found that after harvesting the rice, the amount of the formulated mixture of imazapic and imazethapyr $\left(75+25 \mathrm{~g}\right.$ a.e. $\left.\mathrm{L}^{-1}\right)$ in the soil ranged from 190 to $500 \mathrm{~mL}$ $\mathrm{ha}^{-1}$. From this it can be inferred that all species with a $\mathrm{GR}_{50}$ equal to or greater than these values have the capacity for the phytoremediation of soils contaminated with these herbicides.

\section{CONCLUSIONS}

1. Glycine max, Lolium multiflorum and Lotus corniculatus, duetobeing more adapted tohydromorphic environments, a feature found in soils cultivated with irrigated rice, are potentially promising species in the phytoremediation of soils contaminated with the herbicide imazethapyr + imazapic (up to 4,000 $\mathrm{mL} \mathrm{ha}^{-1}$ );

2. Crotalaria juncea, Canavalia ensiformis, Stizolobium aterrimum, Vicia sativa, Raphanus sativus and Triticum aestivum are species capable of the phytoremediation of soils contaminated with imazethapyr + imazapic, however the occurrence of anoxia in hydromorphic soils reduce the establishment and development of these plants.

\section{REFERENCES}

CARVALHO, A. M. et al. Teores de hemiceluloses, celulose e lignina em plantas de cobertura com potencial para sistema plantio direto no Cerrado. Embrapa Cerrados, 2010. (Boletim de pesquisa e desenvolvimento, 290).

CORREA, M. et al. Seletividade da soja transgênica tolerante ao glyphosate e eficácia de controle de Commelina benghalensis com herbicidas aplicados isolados e em misturas. Bragantia, v. 67, n. 3, p. 663-671, 2008.

CHRISTOFFOLETI, P. J.; LÓPEZ-OVEJERO, R. F. Definições e situação da resistência de plantas daninhas aos herbicidas no Brasil e no mundo. In: CHRISTOFFOLETI, P. J. (Coord.). Aspectos de resistência de plantas daninhas a herbicidas. 2 . ed. Campinas: Associação Brasileira de Ação a Resistência de Plantas aos Herbicidas, 2004. p. 3-22.

DAN, H. A. et al. Atividade residual de herbicidas préemergentes aplicados na cultura da soja sobre o milheto cultivado em sucessão. Planta Daninha, v. 29, n. 2, p. 437445, 2011.

D'ANTONINO, L. et al. Efeitos de culturas na persistência de herbicidas auxínicos no solo. Planta Daninha, v. 27, n. 2 , p. 371-378, 2009.

EMPRESA BRASILEIRA DE PESQUISA AGROPECUÁRIA. Sistema Brasileiro de Classificação de Solo. 2. ed. Rio de Janeiro: EMBRAPA, 2006. 306 p.
FRANS, R. et al. Experimental design and techniques for measuring and analysing plant responses to weed control practices. In: CAMPER, N. D. (Ed.) Research methods in weed science. 3 ed. Champaign: Southern Weed Science Society, 1986. $37 \mathrm{p}$.

FUKUSHIMA, R. S.; SAVIOLI, N. M. F. Correlação entre digestibilidade In vitro da parede celular e três métodos analíticos para a avaliação quantitativa da lignina. Revista Brasileira de Zootecnia, v. 30, n. 2, p. 302-309, 2001.

HALL, L. M.; STROME, K. M.; HORSMAN, G. P. Resistance to acetolactate synthase inhibitors and quinclorac in a biotype of false clover (Gallium spurium). Weed Science, v. 46, n. 1, p. 390-396, 1998.

MADALÃO, J. C. et al. Susceptibilidade de espécies de plantas com potencial de fitorremediação do herbicida sulfentrazone. Revista Ceres, v. 60, n. 1, p. 111-121, 2013.

MARCHESAN, E. et al. Arroz tolerante a imidazolinonas: banco de sementes de arroz-vermelho e fluxo gênico. Planta Daninha, v. 29, p. 1099-1105, 2011. Número Especial.

MARQUES, M. Desafios técnicos e barreiras sociais, econômicas e regulatórias na fitorremediação de solos contaminados. Revista Brasileira de Ciência do Solo, v. 35, n. 1, p. 1-11, 2011.

MARTINI, L. F. D. et al. Lixiviação de imazethapyr + imazapic em função do manejo de do arroz. Planta Daninha, v. 29, n. 1, p.185-193, 2011.

PIRES, F. R. et al. Fitorremediação de solos contaminados com herbicidas. Planta Daninha, v. 21, n. 2, p. 335-341, 2003.

PROCÓPIO, S. O. et al. Potencial de espécies vegetais para a remediação do herbicida trifloxysulfuron-sodium. Planta Daninha, v. 23, n. 1, p. 9-16, 2005a.

PROCÓPIO, S. O. et al. Fitorremediação de solo contaminado com trifloxysulfuron-sodium por mucunapreta (Stizolobium aterrimum). Planta Daninha, v. 23, n. 4, p. 719-724, 2005b.

PROCÓPIO, S. O. et al. Fitorremediação de solo contaminado com trifloxysulfuron-sodium por diferentes densidades populacionais de feijão-de-porco (Canavalia ensiformis (L). DC.). Ciência e Agrotecnologia, v. 30, n. 3, p. 444-449, 2006.

PROCÓPIO, S.O. et al. Fitorremediação de solo contaminado com picloram por capim-pé-degalinha-gigante (Eleusine coracana). Revista Brasileira de Ciência do Solo, v. 32, n. 6, p. 2517-2524, 2008.

SEEFELDT, S. S; JENSEN, J. E; FUERST, P. Log-logistic analysis of herbicide dose-response relationships. Weed Technology, v. 9, n. 2, p. 218-225, 1995.

SENSEMAN, S. A. (Ed.). Herbicide handbook. 9. ed. Lawrence: Weed Science Society of America, 2007. p. 82-89.

SOUTO, K. M. et al. Biodegradação dos herbicidas imazetapir e imazapique em solo rizosférico de seis espécies vegetais. Ciência Rural, v. 43, n. 10, p. 1790-1796, 2013. 
SPILBORGHS, M. C. F.; CASARINI, D. C. P. Biorremediação do solo contaminado com compostos orgânicos. Revista Meio Ambiente Industrial, v. 8, n. 12, p. 66-69, 1998.

STEELE, G. L. et al. Control of redrice (Oryza sativa) in imidazolinone-tolerant rice (Oryza sativa). Weed Technology, v. 16, n. 3, p. 627-630, 2002.

SULMON, C. et al. Sucrose amendment enhances phytoaccumulation of the herbicide atrazine in Arabidopsis thaliana. Environmental Pollution, v. 145, n. 2, p. 507-515, 2007.
VILLA, S. C. C. et al. Arroz tolerante a imidazolinonas: controle do arroz-vermelho, fluxo gênico e efeito residual do herbicida em culturas sucessoras não-tolerantes. Planta Daninha, v. 24, n. 4, p. 761-768, 2006.

WEBSTER, E. P.; MANSSON, J. A. Acetolactate synthaseinhibiting herbicides on imidazolinonas-tolerant rice. Weed Science, v. 49, n. 5, p. 652-657, 2001.

YOSHIDA, S. Fundamentals of rice crop science. Manila: The International Rice Research Institute, 1981. 269 p. 